\title{
Tissue Expander-Implant Breast Reconstruction
}

National Cancer Institute

\section{Source}

National Cancer Institute. Tissue Expander-Implant Breast Reconstruction. NCI

Thesaurus. Code C160627.

A method of breast reconstruction. During the mastectomy procedure a tissue expander is implanted beneath the chest wall muscle. Over a period or weeks or months the volume of the implant is increased, causing the overlying muscle and skin to stretch. Later, the expander is removed and replaced by a permanent breast implant. 